\title{
THE EFFECTS OF ENRICHED Moina ON THE GROWTH, SURVIVAL, AND PROXIMATE ANALYSIS OF MARINE SHRIMP (Penaeus monodon)
}

\author{
NADIAH W. RASDI*1,2, MHD IKHWANUDDIN ${ }^{3}$, SYAMIMI AZMAN ${ }^{1}$, MURNI KARIM ${ }^{4}$, \\ FADHIL SYUKRI ${ }^{5}$ AND ATSUSHI HAGIWARA ${ }^{6}$
}

${ }^{I}$ Faculty of Fisheries and Food Science, ${ }^{2}$ Institute of Tropical Biodiversity and Sustainable Development, ${ }^{3}$ Institute of Tropical Aquaculture \& Fisheries, Universiti Malaysia Terengganu, Kuala Nerus, 21030 Terengganu, Malaysia. ${ }^{4}$ International Institute of Aquaculture and Aquatic Sciences (I-AQUAS), Universiti Putra Malaysia, Lot 960 Jln Kemang 6, 71050 Port Dickson, Negeri Sembilan. ${ }^{5}$ Faculty of Agriculture, Universiti Putra Malaysia, 43400 UPM Serdang, Selangor Darul Ehsan, Malaysia. ${ }^{6}$ Nagasaki Universiti, 1-14 Bunkyomachi, Nagasaki 852-8521, Japan.

*Corresponding author: nadiah.rasdi@umt.edu.my

Submitted final draft: 21 June $2020 \quad$ Accepted: 21 June $2020 \quad$ http://doi.org/10.46754/jssm.2021.04.005

\begin{abstract}
There has been high demand in aquaculture for live feed as a starter feed for fish and crustacean larvae. The Moina sp is a potential live-feed species due to its availability in most of the natural water resource, high nutritional value and the potential to replace other types of zooplankton, which are commonly used in aquaculture, such as Artemia. This study aims to compare the survival, growth, and proximate analyses of Penaeus monodon larvae fed with different enriched Moina sp. The Penaeus monodon larvae, which are fed on Moina sp were enriched with different formulas, comprising yeast, canola oil, Nannochloropsis sp, and Chlorella sp. This study was conducted at the hatchery of Faculty of Fisheries and Food Sciences (FPSM) in Universiti Malaysia Terengganu. The Moina sp. was cultured for 6 generations before starting the experiment. Enriched Moina sp was placed in triplicates in an aquarium, reared for 30 days, and fed to 450 individuals. The highest specific growth rate of $P$. monodon was recorded when fed with Moina-enriched yeast $(17.22 \pm 0.10 \%)$ with a survival rate of $91.78 \pm 1.67 \%$. Overall, the Moina-enriched yeast displayed the best result compared to other enrichment methods, especially towards the biochemical compositions of the shrimp. The mean value of protein, lipid, moisture and ash amounted to $64.04 \pm 0.40 \%, 4.91 \pm 2.43 \%, 16.89 \pm 2.75 \%$, and $10.38 \pm 2.05 \%$ respectively. It was found that the enrichment methods using yeast were effective on Moina $\mathrm{sp}$, and improved the nutritional composition of shrimp larvae and the larval performance of $P$. monodon postlarvae production in hatcheries by utilising low-cost enriched Moina sp as live food..
\end{abstract}

Keywords: Moina, enrichment, Penaeus monodon, proximate analysis, growth and survival.

$\begin{array}{ll}\text { Abbreviations: } \\ \text { PL } & \text { : Postlarvae } \\ \text { ppt } & \text { : part per thousand } \\ \text { SGR } & \text { : Specific Growth Rate } \\ \text { sp. } & \text { : species }\end{array}$

\section{Introduction}

There has been a high demand for live food in aquaculture industries as a starter feed for fish and crustaceans. Similarly, the zooplankton and phytoplankton have also become an essential component in aquatic food webs and for the growth of fish and shellfish in aquaculture hatcheries. Small and semi-developed mouth sizes of newhatch larvae need appropriately sized food (Cary et al., 2004). Notably, most widely used live food for larval and postlarval shrimps are Artemia and rotifers (Brachionus plicatilis). Furthermore, with its wide use as live food, Artemia nauplii contains an ideal live food organism for shrimp feeding. . However, the most significant disadvantage of Artemia is the marked variation in cost. Although Artemia production has been proposed and widely used as a solution to this shortcoming (Hamre et al., 2016), enriched Artemia also has drawbacks, 
including unstable biological composition after enrichment (Olsen et al., 2000). Therefore, the possible solutions to these shortcomings are the introduction of the other live-food organisms, such as copepods and Moina sp, which have been extensively utilised as live food (Naman et al., 2021). Additionally, the commercial importance of live food has been maintained as a continuous culture in many hatcheries (Martin et al., 2003).

The primary focus in aquaculture is the production of sustainable live-feed sources with high nutritional value due to the currently increasing demand for natural food. However, the current issue with live-feed culture is a low production rate, which could not fulfil the high demand from aquaculture hatcheries (Bryan et al., 2008). The production of tiger shrimp broodstock from closes-culture systems is also faced with several constraints, including low number of matured females due to the unsynchronised gonad maturation between male and female stocks, low mating rate, delayed spawning time, low hatching rate and, most importantly, low survival of post-larvae during the critical stage of development due to nutrient inadequacy (Uawisetwathana et al., 2011; Marsden et al., 2013). Meanwhile, protein is the primary concern in fish or crustacean culture. The quality of cultured water may be easily deteriorated by the use of artificial diets, such as egg yolk suspension and milk powder or powdered feed used to feed the larvae (Lim et al., 2003). Shrimp production is also having the problem of the high cost of commercial feeds, which increases from time to time (Ayisi et al., 2017).

The primary production of zooplankton plays a significant role in the aquatic environment (Iannacone et al., 2007; Rasdi et al., 2018c). It is broadly used to standardise the locality of laboratory ecotoxicol bioassays (Nandini et al., 2004; Sarma et al., 2006; Iannacone et al., 2007). Fish larvae, which feed on zooplankton, are known for having a better survival rate compared to other types of live food (Rasdi et al., 2018a). The Moina sp have also been proven to have the potential as an alternative to the more expensive Artemia and other seasonal zooplankton, such as rotifers in larviculture (Das et al., 2007). Cladocerans species is suitable for mass production due to the rapid population growth, short generation time and the ability to fulfil the nutrient requirements of the larvae diet (Yuslan et al., 2021). During the exogenous feeding stage, as the mouth of the larvae is usually small, food size which is smaller than the larvae mouth is required.

The quantity of nutrients received from the type of feed will affect the population growth and reproduction of species (Müller et al., 2000). Previous study from Nandini et al. (2013) found that poor diets or poor quality nutrient resources for Moina sp will affect population growth and survival, which were dominated by smaller sized individuals as more generations cannot be produced in the culture. Therefore, optimum nutritional value and sufficient stock culture as a feed for crustacean larvae could not be achieved. Hence, finding a suitable diet and enrichment was important to ensure optimum nutrients could be obtained for good growth and survival of Moina sp. (Samat et al., 2020). A study by Singh et al. (2019) found that Moina sp has shortages of nutrients needed for growth and survival of predator fish and crustacean larvae, certainly in essential $n-3$ highly unsaturated fatty acids, including EPA (eicosapentaenoic acid) and DHA (Docosahexaenoic acid). Thus, there is a need to enhance the nutritional quality by enriching them by pre-feeding the zooplankton including Moina sp (Scott \& Middleton, 1979; Das et al., 2007).

Apart from that, the suitability of Penaeus monodon for farming is clearly due to rapid growth and high market value. The cultures of shrimp are prioritised due to unique taste, the high nutritive value of body composition and fulfilment of the world market demand (Shailender et al., 2012). Furthermore, penaeid shrimps are among the highly in demand seafood commodities, while cultured shrimp contributes to a major share of global shrimp production. The global growth of the shrimp industry is due 
to the increased seafood demand and economic return (Panantharayil et al., 2015). However, nutrition remains the major constraint during the critical stages of shrimp development, which leads to mortality due to inadequate live food sources in the hatcheries. Besides, this issue stems from the limited amount of nutrients being made available by the common zooplankton used in aquaculture.

The aim of this study is to improve the production of commercial marine shrimp ( $P$. monodon) and evaluate the effects of enriched Moina sp on growth performance, survival rate of $P$. monodon and proximate analysis of $P$. monodon and Moina $\mathrm{sp}$ in hatchery reared conditions. This study also calculates the efficiency of enrichment types on Moina $\mathrm{sp}$ and the specific growth rate, survival rate and proximate analysis of marine shrimp $P$. monodon and Moina sp.

\section{Materials and Methods}

\section{Sampling and Moina sp. Stock Culture}

Samples of Moina sp from the swamp around Universiti Malaysia Terengganu was used in this study. The wild Moina sp was then cultured and sustained in the hatchery of Faculty of Fisheries and Food Sciences (FPSM) in Universiti Malaysia Terengganu since September 2018. As the salinity and optimal temperature range for the larvae habitat were maintained from $24^{\circ} \mathrm{C}$ to $31^{\circ} \mathrm{C}$, as reported by Rottmann et al (2014). The stock culture was upscaled and sustained for subsequent generations in the mass culture condition. Furthermore, the cultured water used in this study was prepared and maintained by changing 20\% (Rasdi et al., 2018) of the water every two days to avoid stress and contamination of the Moina sp culture. Daily observation on Moina sp. was then conducted, followed by siphoning the mosses in the tank to avoid any contamination.

\section{Experimental Design and Diet Preparation}

The experiments were performed for 30 days between November 1st until November 30th, 2018. Moina sp were enriched by four types of feeding treatments, including canola oil, yeast, and microalgae (Chlorella sp and Nannochloropsis sp). Preparation methods for canola oil enrichment were used by previous researchers (Estevez et al., 2008; Ghader et al., 2015), where L-a- phosphatidylcholine (Sigma-Aldrich, USA) was added to the oil in the ratio of $1: 4(\mathrm{w}: \mathrm{w})$ to produce a stable emulsion to prevent the separation of oil from other elements. A mortar and pestle were used. With a concentration of $2000 \mathrm{mg} / \mathrm{L}$ (Loh et al., 2012), the canola oil was fed to Moina sp. All of the microalgae were cultured in the laboratory at UMT hatchery, and the quality of the medium (Conway medium) used for cultivation determined their growth performance (Lam et al., 2012; Jusoh et al., 2020). Following that, the 5,000 individuals per litre of Moina sp (Rottman et al., 2014) from stock was transferred into 10 L aquariums for enrichment. Moina sp were fed with four different types of enrichment diets within 24 hours (Shepard, 2015). The enrichment tanks were placed in an outdoor hatchery under direct sunlight for 12 hours of light/dark period. Each tank was gently aerated to keep oxygen levels between $4.0 \mathrm{mg}$. $\mathrm{l}^{-1}$ to 5.5 mg. $1^{-1}$. After the enrichment, the Moina sp was then obtained directly from the treatment tank using plankton net $50 \mu \mathrm{m}$ to $150 \mu \mathrm{m}$ before being fed to $P$. monodon.

Four treatment diets were prepared with triplicates and fed to the Moina sp daily to determine the difference between nutrient content and each treatment. The concentration of Chlorella sp and Nannochloropsis sp fed to the Moina sp was $25.03 \mathrm{mg} / \mathrm{L}$, which was equivalent to $1 \times 10^{7}$ algal cells $/ \mathrm{mL}$ (Zaleha \& Busra, 2012). Meanwhile, the yeast was fed with inert feeds, which included baker's yeast (Saccharomyces cerevisiae) (Munirasu et al., 2016) with a concentration of $0.0005 \mathrm{~g} /$ $\mathrm{mL}$ (Paray et al., 2016). The Moina sp. was transferred first from the stock culture to the $100 \mathrm{~L}$ tank and fed to the dietary treatments. The treatment used for the enrichment of Moina sp and the diet for test feeding to P. monodon postlarvae consisted of four types - Moina-enriched 
Nannochloropsis sp, Chlorella sp, canola oil, and yeast.

\section{Penaeus monodon Postlarvae Culture}

The post-larvae (PL15) of P. monodon were cultured in the hatchery of Universiti Malaysia Terengganu. The P. monodon PL15 amounted to 150 individuals in each aquarium, and $20 \mathrm{~L}$ of water cultured in $25 \mathrm{~L}$ aquariums and aeration was provided for the feeding experiment. The experiment was divided into four groups based on different types of enriched live-feed treatments, while 450 replicates of post-larvae were used for each dietary treatment. All treatments in the feeding trials consumed four different types of enriched Moina sp, each consisting of three replicates. The salinity of the PLs was maintained at the range of $24 \mathrm{ppt}$ to $26 \mathrm{ppt}$ and temperature range of $26^{\circ} \mathrm{C}$ to $28^{\circ} \mathrm{C}$ (Wong et al., 2015). Furthermore, the PL of experimental groups was fed from 8 a.m. to 10 a.m. and 4 p.m. to 6 p.m. Meanwhile, after hours of feeding through the siphoning method, the unfed Moina $\mathrm{sp}$ was removed from the rearing tank. Moreover, mild aeration was supplied continuously to maintain the optimal oxygen level, and the water exchange medium was changed once a week to ensure minimum disturbance to the post-larvae. Water quality parameters, including salinity, temperature, dissolved oxygen and $\mathrm{pH}$ were strictly maintained and monitored throughout the experimental period on a weekly basis to ensure that the ammonia concentration was below the threshold levels.

\section{Growth and Survival of Penaeus monodon}

The growth of $P$. monodon was analysed by measuring the length and weight of the postlarvae every six days throughout the experiment period. Gentle aeration was provided and water quality monitoring was adopted in order to promote proper growth and increased postlarvae survival rates ( $\mathrm{Ng}$ et al., 2015).

To calculate the growth of $P$. monodon, 10 post-larvae were randomly sampled for every treatment in each replicate. The weight of the sample was calculated to determine the growth of post-larvae, which was then recorded using an electronic weighing scale with an accuracy of 0.001 g. Specific growth rate (SGR) was calculated from the density data using the following formula by (Lee et al., 2013; Rasdi \& Qin 2018):

Specific growth rate $=(\mathrm{Ln} \mathrm{Ne}-\mathrm{Ln} \mathrm{Ni}) / \mathrm{t}$

Where Ni refers to the initial density of postlarvae, $\mathrm{Ne}$ represents the end density of post-larvae, and t represents time. The density of post-larvae was calculated based on $\mathrm{Nf}-\mathrm{N}$, where Nf which represents the number of living prawn at the end of the experiment, while $\mathrm{N}$ represents the number of post-larvae stocked at the beginning of the experiment.The data of the survival of each treatment were calculated and recorded daily using the following formula (Pachaan et al., 2017):

$=$ Total number of post-larvae survive in last day/total number of postlarvae on initial day $x$ 100

\section{Proximate Analysis of Penaeus Monodon and Moina sp.}

The weights of the sample were measured and collected in a separate polyethylene bags and stored in the freezer at $-20{ }^{\circ} \mathrm{C}$ before being dried for two days in an oven at $60{ }^{\circ} \mathrm{C}$. Analysis on the protein, lipid, moisture, and ash was performed at the Fish Nutrition Laboratory (FNL) of Faculty of Fisheries and Food Sciences in Universiti Malaysia Terengganu. Evaluation of each proximate analysis parameter were done based on the following formula:

Estimation of protein; (Maehre et al., 2016)

$$
\begin{gathered}
\text { Percentage }(\%) \text { of proteins } \\
=(\mathrm{c}-\mathrm{b}) \times 14 \times \mathrm{d} \times 6.25 / \mathrm{a} \times 1000 \times 100
\end{gathered}
$$

Where, $\mathrm{a}=$ sample weight in $\mathrm{g}, \mathrm{b}=$ volume of $\mathrm{NaOH}$ required for back titration and neutralisation with $25 \mathrm{ml}$ of $0.1 \mathrm{~N} \mathrm{H}_{2} \mathrm{SO}_{4}$ (for sample), $\mathrm{c}=$ volume of $\mathrm{NaOH}$ required for back titration and neutralisation with $25 \mathrm{ml}$ of $0.1 \mathrm{~N}$ $\mathrm{H}_{2} \mathrm{SO}_{4}$ (for blank), $\mathrm{d}=$ normality of $\mathrm{NaOH}$ used for titration process, $6.25=$ conversion factor of Nitrogen to protein, and $14=$ atomic weight of Nitrogen. 
Estimation of lipids; (Gong et al., 2000)

Percentage (\%) of lipids

$=($ Weight of the extract/Weight of sample $) \times$ 100

Estimation of moisture; (Jain et al., 2000)

Percentage (\%) of moisture

$=$ (weight loss/ original weight of sample taken $)$ $\times 100$

Estimation of Ash; (AOAC, 2000)

Percentage (\%) of ash

$=($ Weight of ash/Weight of sample $) \times 100$

\section{Data Analysis}

Data were presented as Mean \pm Standard deviation (SD). All data were collected throughout the experiment and analysed with one-way analysis of variance (ANOVA) using the IBM SPSS statistic 26.0 package for Windows to see the impacts of different diets on the growth, survival of $P$. monodon and proximate analysis of $P$. monodon and Moina sp. Differences were considered significant at the $P$ $<0.05$ level. When the main treatment effect was significant, Post-Hoc comparisons were made using Tukey's test. All the data were tested for normality, homogeneity and independence to satisfy the assumptions for ANOVA.

\section{Results and Discussion}

\section{Survival Rate}

P. monodon fed on Moina sp-enriched yeast was found to have the highest survival rate compared to the larvae fed with other enrichment methods (92.00\% \pm 1.0$)$, followed by Chlorella $\mathrm{sp}(87.33 \%$ $\pm 2.51)$ and Nannochloropsis sp. $(83.33 \% \pm$ 1.52). Nevertheless, there was no significant difference between canola oil, Nannochloropsis $\mathrm{sp}$, Chlorella sp, and yeast in terms of survival rate, where $(\mathrm{P}>0.05)$. The average survival rate illustrated in Table 1 depended on the types of enrichment incorporated in each dietary treatment. Meanwhile, P. monodon, which fed on the Moina sp enriched with canola oil exhibited the lowest survival rate among other larvae $(78.33 \% \pm 5.03)$, with a significant difference of $(P<0.05)$.

\section{Specific Growth Rate}

Table 1 shows $P$. monodon fed on Moina sp-enriched yeast, exhibited better growth performance compared to other treatments $(17.22 \pm 0.10)$. Meanwhile, the incorporation of canola oil into its treatments resulted in the lowest growth rate with a significant difference of $(P<0.05)$ among all the treatments.

Table 1: The survival rate and specific growth rate of P. monodon post-larvae fed with various enrichments of Moina sp and diets. All values mean \pm standard deviation was represented by $(n=3)$. The small letters indicate a significant difference between different treatments $(\mathrm{P}<0.05)$

\begin{tabular}{lcc}
\hline \multicolumn{1}{c}{ Diets } & $\begin{array}{c}\text { Survival rate }(\%) /(\text { mean } \\
\pm \mathbf{S D})\end{array}$ & Specific growth rate $(\%) /($ mean \pm SD) \\
\hline Nannochloropsis sp. & $83.33 \pm 1.52^{\mathrm{bc}}$ & $16.99 \pm 0.76^{\mathrm{b}}$ \\
Chlorella sp. & $87.33 \pm 2.51^{\mathrm{ab}}$ & $17.14 \pm 0.88^{\mathrm{ab}}$ \\
Canola oil & $78.33 \pm 5.03^{\mathrm{c}}$ & $16.96 \pm 0.67^{\mathrm{b}}$ \\
Yeast & $92.00 \pm 1.0^{\mathrm{a}}$ & $17.22 \pm 0.10^{\mathrm{a}}$ \\
\hline
\end{tabular}




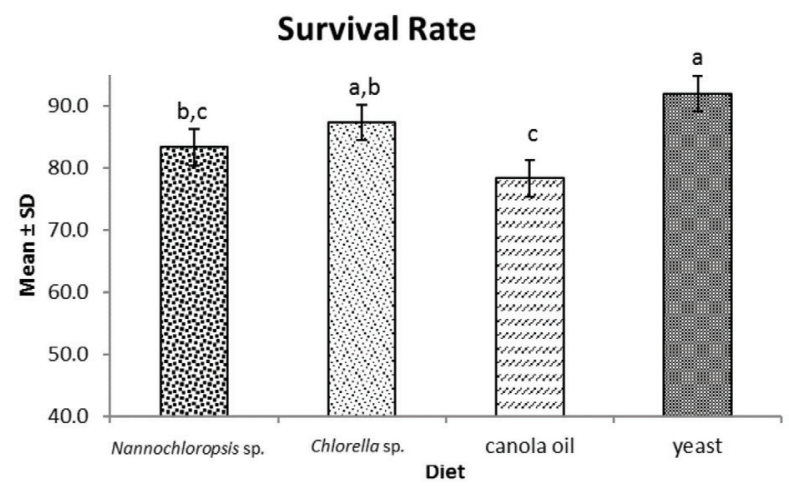

Figure 1: Survival rate of $P$. monodon fed with different types of enriched Moina sp. The small letters indicate a significant difference between different treatments $(\mathrm{P}<0.05)$

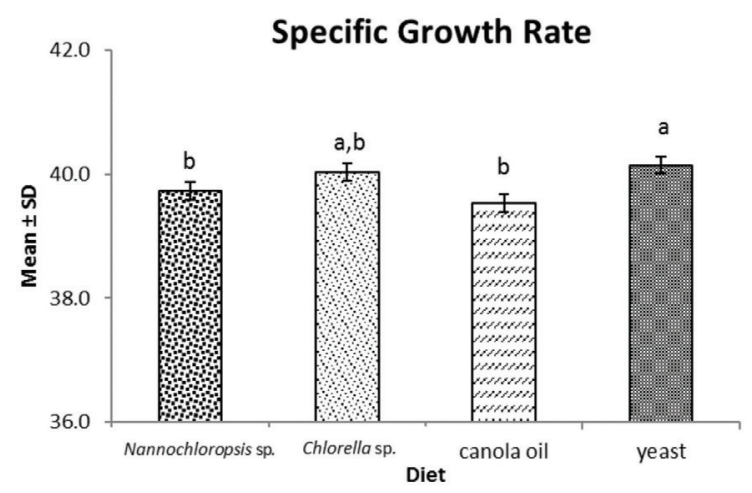

Figure 2: Specific growth rate of P. monodon fed with different types of enriched Moina sp. The small letters indicate a significant difference between different treatments $(\mathrm{P}<0.05)$

\section{Proximate Analysis of Penaeus monodon}

The proximate analysis of Penaeus monodon consisted of protein, lipid, moisture and ash analyses. As a result, the mean \pm S.D of proximate analysis of Penaeus monodon fed on different enrichment of Moina sp, was obtained, as shown in Table 1. The protein content in $P$. monodon fed on Moina sp-enriched yeast was higher compared to the protein content in the other enrichment formula. Meanwhile, the lipid content of P. monodon fed on Moina sp-enriched canola oil (2.62 \pm 0.58$)$ and Nannochloropasis sp $(3.52 \pm 2.43)$ were lower compared to the larvae enriched with yeast and Chlorella sp, although the difference between the contents was not significant $(P>0.05)$. Moreover, it was shown from the moisture analysis of $P$. monodon that the enrichment method which incorporated canola oil led to the lowest moisture content. Overall, the postlarvae fed with yeast displayed the best result in terms of protein, lipid, moisture and ash content, with $64.04 \pm 0.40 \%, 16.89$ $\pm 2.75 \%$, and $10.38 \pm 2.05 \%$ mean \pm S.D respectively. 


\section{Proximate Analysis of Moina sp.}

Table 2: The body composition of P. monodon post-larvae fed with four different enrichments of Moina $\mathrm{sp}$ and diets. All values mean \pm standard deviation was represented by $(\mathrm{n}=3)$. The small letters indicate the significant difference between treatments $(\mathrm{P}<0.05)$

\begin{tabular}{|c|c|c|c|}
\hline \multirow[t]{2}{*}{ Body Composition } & \multirow[t]{2}{*}{ Enrichment } & \multicolumn{2}{|c|}{ Mean \pm SD (\%) } \\
\hline & & Penaeus monodon & Moina sp. \\
\hline \multirow[t]{4}{*}{ Protein } & Nannochloropsis sp. & $63.09 \pm 0.50^{\mathrm{a}}$ & $49.49 \pm 0.56^{b}$ \\
\hline & Chlorella sp. & $63.49 \pm 0.28^{\mathrm{a}}$ & $50.74 \pm 0.42^{\mathrm{ab}}$ \\
\hline & Canola oil & $61.08 \pm 1.25^{\mathrm{b}}$ & $46.03 \pm 0.99^{c}$ \\
\hline & Yeast & $64.04 \pm 0.40^{\mathrm{a}}$ & $51.56 \pm 3.69^{\mathrm{a}}$ \\
\hline \multirow[t]{4}{*}{ Lipid } & Nannochloropsis sp. & $3.52 \pm 2.43^{\mathrm{a}}$ & $3.22 \pm 0.09^{\mathrm{ab}}$ \\
\hline & Chlorella sp. & $4.28 \pm 2.61^{\mathrm{a}}$ & $3.69 \pm 0.40^{\mathrm{a}}$ \\
\hline & Canola oil & $2.62 \pm 0.58^{\mathrm{a}}$ & $2.23 \pm 0.50^{\mathrm{b}}$ \\
\hline & Yeast & $4.91 \pm 1.53^{\mathrm{a}}$ & $3.75 \pm 0.70^{\mathrm{a}}$ \\
\hline \multirow[t]{4}{*}{ Moisture } & Nannochloropsis sp. & $13.23 \pm 2.18^{\mathrm{ab}}$ & $11.96 \pm 5.07^{\mathrm{a}}$ \\
\hline & Chlorella sp. & $14.37 \pm 0.70^{\mathrm{ab}}$ & $13.11 \pm 4.66^{\mathrm{a}}$ \\
\hline & Canola oil & $9.21 \pm 2.23^{\mathrm{a}}$ & $9.21 \pm 2.23^{\mathrm{a}}$ \\
\hline & Yeast & $16.89 \pm 2.75^{\mathrm{a}}$ & $13.23 \pm 2.18^{\mathrm{a}}$ \\
\hline \multirow[t]{4}{*}{ Ash } & Nannochloropsis sp. & $5.85 \pm 4.55^{\mathrm{a}}$ & $8.72 \pm 0.07^{\mathrm{a}}$ \\
\hline & Chlorella sp. & $8.06 \pm 0.94^{\mathrm{a}}$ & $10.60 \pm 4.97^{\mathrm{a}}$ \\
\hline & Canola oil & $5.74 \pm 2.82^{\mathrm{a}}$ & $8.67 \pm 4.26^{\mathrm{a}}$ \\
\hline & Yeast & $10.38 \pm 2.05^{\mathrm{a}}$ & $11.58 \pm 3.69^{\mathrm{a}}$ \\
\hline
\end{tabular}


a

\section{Protein}

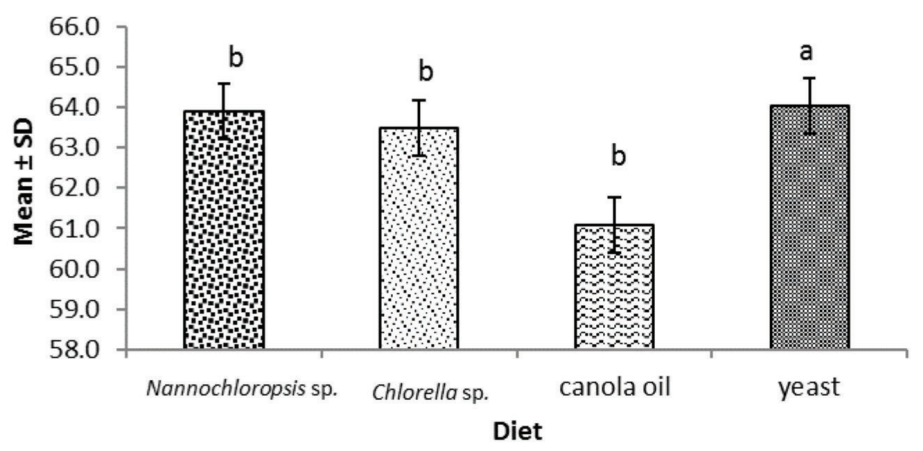

b

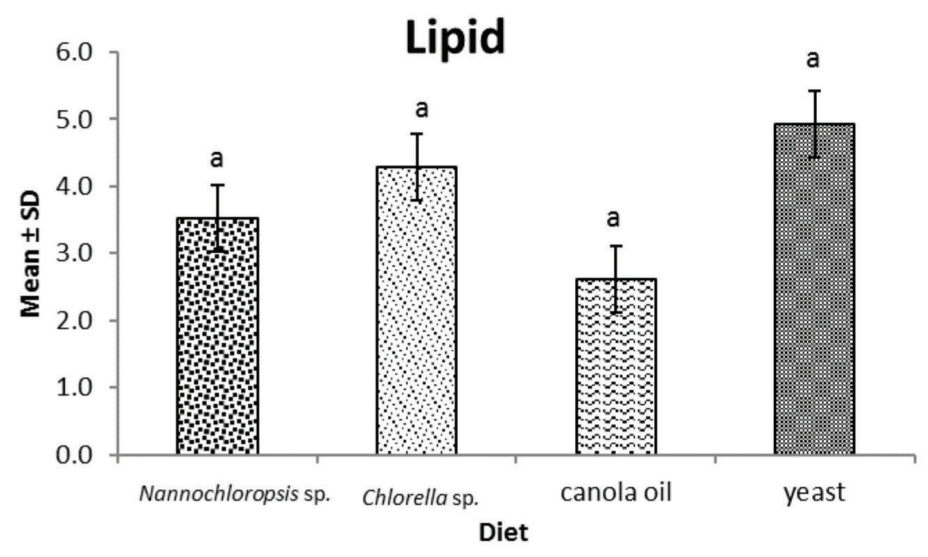

c

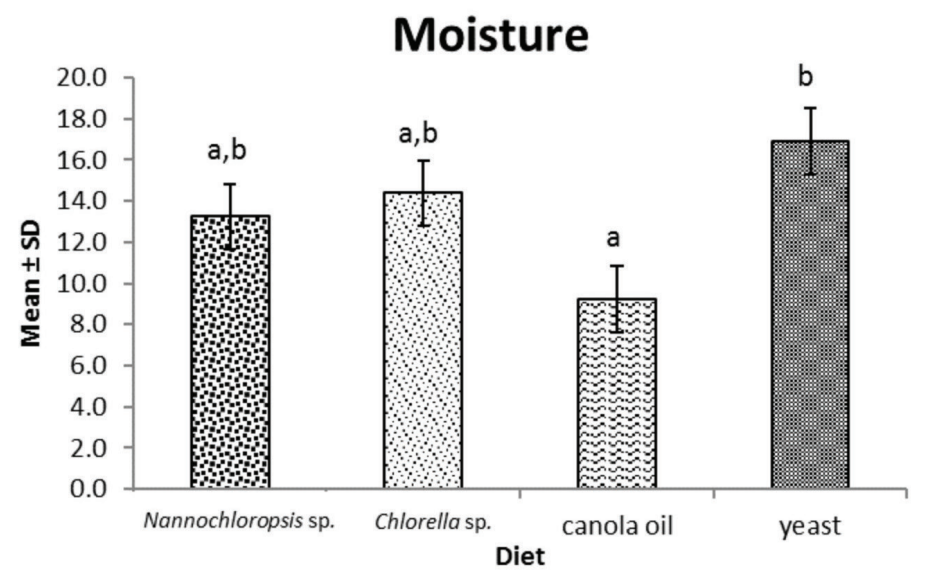




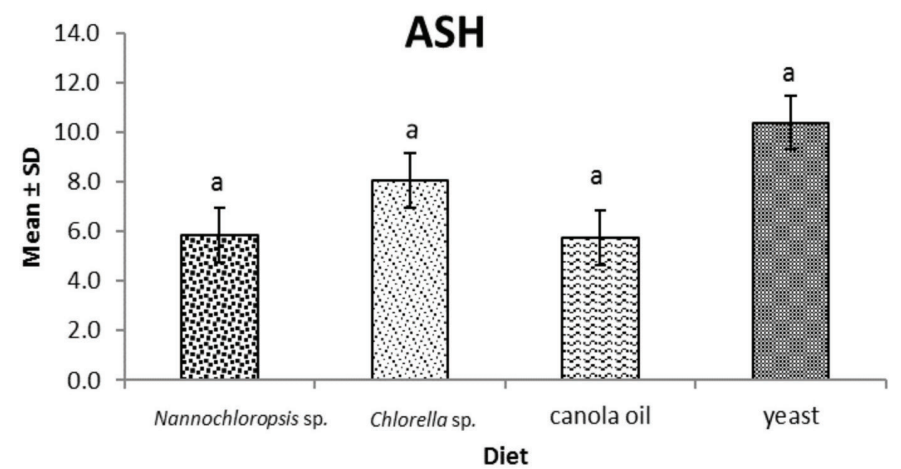

Figure 3: The life table parameter proximate analysis of Penaeus monodon fed on different types of treatment diets. (a) Average of protein analysis (b) Average of lipid analysis (c) Average of moisture analysis (d) Average of ash analysis. The small letters indicate a significant difference between different treatments $(\mathrm{P}<$ $0.05)$

a

\section{Protein}

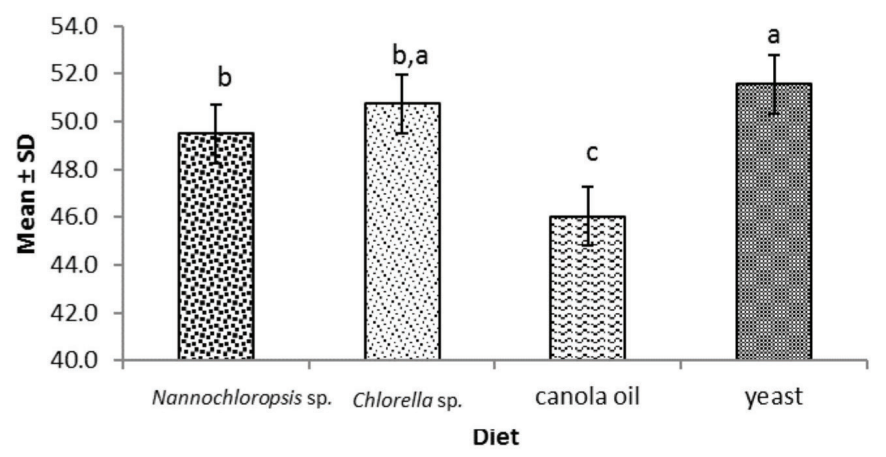

$\mathrm{b}$

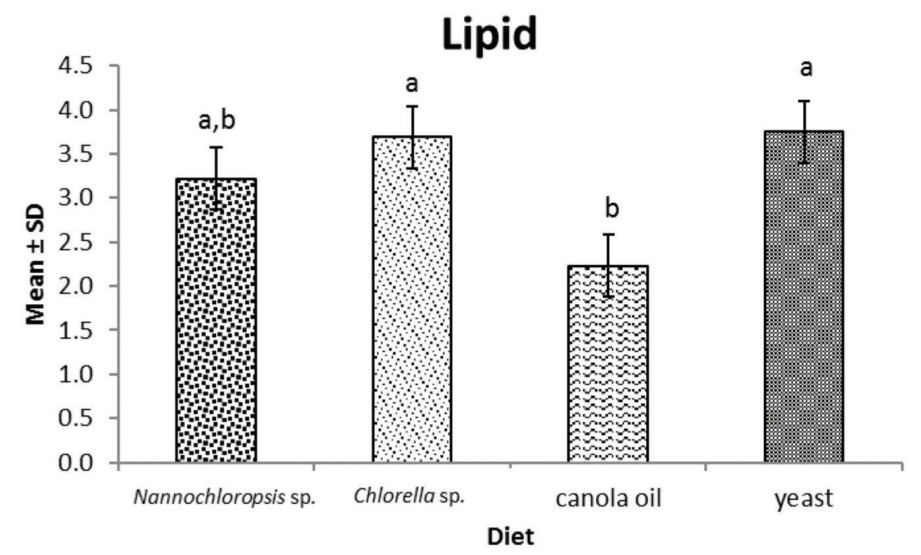


c

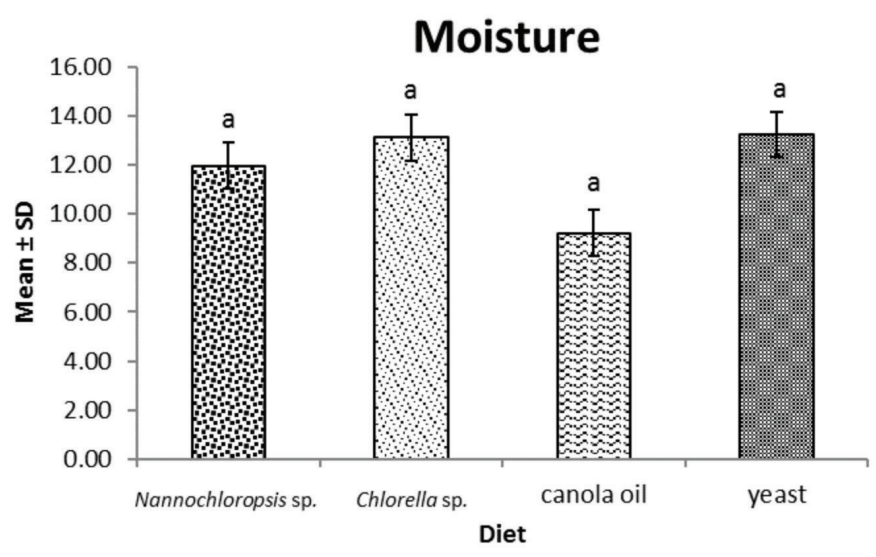

d

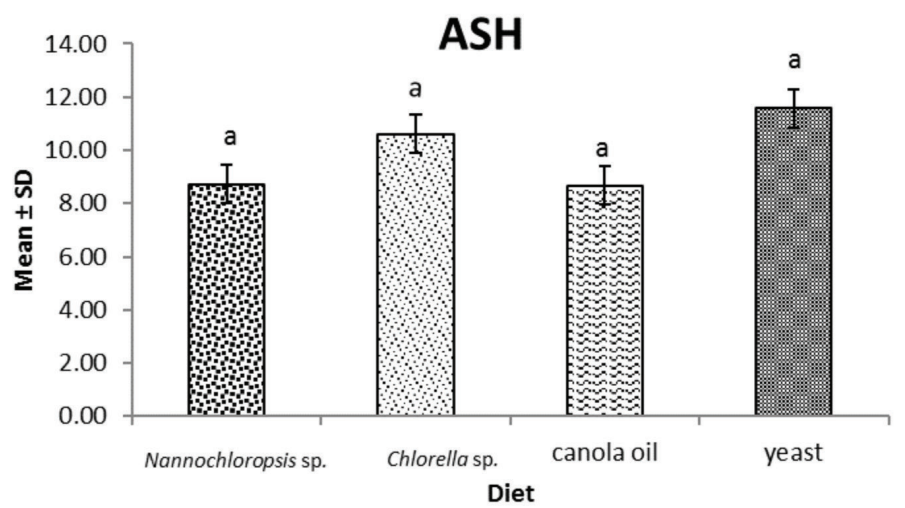

Figure 4: The proximate analysis of Penaeus monodon fed on different types of treatment diets. (a) Average of protein analysis (b) Average of lipid analysis (c) Average of moisture analysis (d) Average of ash analysis.

The small letters indicate a significant difference between different treatments $(P<0.05)$

Based on the table above, it was found that the nutrient content in the body composition of Moina sp was highest in Moina sp-enriched yeast, with a protein content of $51.56 \pm 3.39$. Furthermore, while the enrichment with canola oil led to the lowest value of lipid (2.23 \pm 0.50 ), the moisture content of Moina sp was the highest among all treatments $(13.23 \pm 2.18)$, which was followed by the moisture content of Chlorella sp (13.11 \pm 4.66), Nannochloropsis sp $(11.96 \pm 5.07)$, and canola oil $(9.21 \pm 2.23)$. However, there was no significant difference $(P$
$>0.5$ ) among the four treatment diets in terms of moisture and ash contents.

One of the main strategies of developing a larval rearing system is the establishment of a feeding regime, which will result in optimal growth and higher survival rate of the larvae. The differences in the growth and survival of P. monodon postlarvae may be attributed to quality preference, consumption, and digestion of diets. In this study, the Moina sp. enriched with yeast resulted in better growth performance and survival rate of $P$. monodon, which was similar with the result from Scylla serrata, when 
it was fed on Moina sp-enriched-yeast with a survival rate of $92.5 \%$ and SGR of $10.55 \%$ per day. Meanwhile, the survival rate of $P$. monodon amounted to $95.00 \%$, with the SGR amounting to $18.10 \%$ (Zhao et al., 2017).

Although the best growth performance and survival rate were achieved through the treatment with yeast, the Moina sp enriched with Chlorella sp also led to high body composition, which was not significantly different from the results. Therefore, the importance of Moina $s \mathrm{p}$ as live feed was proven in this study. As previous study had also found that the larvae of L. vannamei, which was fed on microalgae Tetraselmis suecia, displayed superior survival rate and growth performance (Sharawy et al., 2020), the result of this study was in agreement with the previous study, where the green algae Chlorella sp also exhibited higher survival rate and growth performance compared to the larvae co-enriched with yeast. Accordingly, it was indicated that Chlorella sp can also be another potential alternative to Tetraselmis sp, which is to be further used in enrichment formulas.

Protein compositions are the sources of essential amino acids, which provide energy for prawn larvae. It was reported by D'Souza et al. (2000) that there was a low possibility for amino acid content of the diets to be the factor of the substantial differences in the development and dry weight of the larvae. Instead, lipids were found to be the sources of energy, which played a role in the build components of the membrane structures of prawn larvae and promoted the moulting hormone of crustaceans (D'Souza \& Kelly, 2000). In this study, the highest protein and lipid in the body composition of $P$. monodon was found when it fed on Moina sp enriched with yeast. Furthermore, a strong composition of yeast and its measurable nutritional value were recorded. Despite the high level of protein in the diets, lipids were reported to contribute to the highest growth performance of juvenile Fenneropenaeus indicus (Sarlin \& Philip, 2016). Besides, high dietary protein led to maximum growth of juvenile pearl oyster Pinctada fucata martensii (Yang et al., 2017) and giant freshwater prawn Macrobrachium rosenbergii
(Nguyen et al., 2019), which was in agreement with the present study.

González-Félix et al. (2002) evaluated different neutral lipids, which resulted in different effects on growth performance, survival rate, and the lipid's potential interaction and nutrition of shrimp muscle tissue of juvenile L. vannamei. The tested lipid sources included coconut, soybean, linseed, peanut, and menhaden oils. As a result, no significant difference $(P>0.05)$ was observed from the treatments in terms of survival rate, and no significant interaction was found between the effects of PL and oil types based on any of the responses in the experiment.

In this study, although no significant difference was found in the lipid content in $P$. monodon body composition $(P<0.05)$, the methods of enrichment used in this study, namely Nannochloropsis sp, Chlorella sp, canola oil, and yeast were considered applicable due to low-cost compared to other enrichment methods used in aquaculture, such as oil emulsion through Super Selco. Furthermore, 1.2 \% of the ash content of the L. vannamei was found, with the ash content of shrimp generally ranging from $1 \%$ to $1.5 \%$. In the studies by Gokoglu et al. (2008) and Yanar et al. (2006), the calculated amount of ash in black tiger and white shrimps was $10.47 \%$ upon consumption of enriched artemia. These values were close to the values shown in the current study findings, which was $10.38 \%$. However, the ash content was recorded to be higher compared to the content recorded in previous research when the $P$. monodon was fed on Moina sp-enriched yeast. Therefore, the use of yeast as enrichment in the zooplankton culture and Moina sp as the live feed for the larvae culture is suggested due to relevance and applicability for further practice.

\section{Conclusion}

In conclusion, $P$. monodon fed on Moina spenriched yeast exhibited the highest nutrient in body composition, which could contribute to the best growth performance of $P$. monodon. This study proved that appropriate feeding of Moina sp ensured adequate nutrients being transmitted 
to $P$. monodon postlarvae. It should be noted in this study that various enrichment methods could be used as a treatment for Moina sp, such as Nannochloropsis sp, Chlorella sp, canola oil, and yeast. Furthermore, the use of yeast as an enrichment for Moina sp indirectly assisted the industry of aquaculture in reducing the cost of production, including conserving time and labour. It was further indicated from these study results that other enrichment protocols could also be applied to enhance the nutrition of shrimp in larviculture. Moreover, the output from this study could be further expanded to identify the genomic effects of these enrichment formulae on Moina sp and shrimp after consuming the enriched Moina sp and be applied in further investigation and research. Further studies on the value of yeast as a source of protein in the formulated diet of $P$. monodon are recommended, including the exploration of other protein sources, which are locally available. These protein sources could add variety to the feed available to aquaculturists to ensure successful propagation of shrimp culture during the critical stages of development.

\section{Acknowledgements}

The Malaysian Ministry of Higher Education (MOHE) Fundamental Research Grant Scheme (FRGS) endorsed this study with vote number 59530, with an aim to develop new ideas and methods for aquaculture growth in Malaysia. The author declared that there was no conflict of interest in the formation of this manuscript.

\section{References}

Agh, N., \& P. Sorgeloos. (2005). Handbook of protocols and guidelines for culture and enrichment of live food for use in larviculture. Urmia-Iran: Ediciones Artemia \& Aquatic Animals Research Center, 60.

AOAC. (2000). Official methods of analysis (17th ed.). Gaithersburg, VA: AOAC International.

Ayisi, C. L., Hua, X., Apraku, A., Afriyie, G., \&
Kyei, B. A. (2017). Recent studies toward the development of practical diets for shrimp and their nutritional requirements. HAYATI Journal of Biosciences, 24(3), 109117.

Bryan, P. L. (2008). Effects of different feeds on the population growth of Moina sp. culture. Perpustakaan Universiti Malaysia Sabah. (Unpublished)

Chu, K. H., \& C. K. Shing (1986). Feeding behaviour of the shrimp, Metapenaus ensis, on Artemia nauplii. Aquaculture, 58, 175184.

D’souza, D. C., Gil, R., Cassello, K., Morrissey, K., Abi-Saab, D., White, J., ... \& Charney, D. S. (2000). IV glycine and oral D-cycloserine effects on plasma and CSF amino acids in healthy humans. Biological Psychiatry, 47(5), 450-462.

Das, S. K., Tiwari, V. K., Venkateshwarlu, G., Reddy, A. K., \& Parhi, J. (2007). Growth, survival and fatty acid composition of Macrobrachium rosenbergii (de Man, 1879) post larvae fed HUFA-enriched Moina micrura. Aquaculture, 269, 464-475. View of methods and applications. Aquaculture, 267, 62- 75.

D’Souza, F. M., \& Kelly, G. J. (2000). Effects of a diet of a nitrogen-limited alga (Tetraselmis suecica) on growth, survival and biochemical composition of tiger prawn (Penaeus semisulcatus) larvae. Aquaculture, 181(3-4), 311-329.

Enright, C. T., Newkirk, G. F., Craigie, J. S., \& Castell, J. D. (1986). Evaluation of phytoplankton as diets for juvenile Ostrea edulis L. Journal of Experimental Marine Biology and Ecology, 96(1), 1-13.

Estévez, M., Kylli, P., Puolanne, E., Kivikari, R., \& Heinonen, M. (2008). Fluorescence spectroscopy as a novel approach for the assessment of myofibrillar protein oxidation in oil-in-water emulsions. Meat Science, 80(4), 1290-1296.

Ghader Poor, S., Agh, N., Noori, F., \& Ahmadian, E. (2015). Introducing standard protocol 
for enrichment of Artemia urmiana nauplii with Canola oil. Journal of Marine Science and Technology, 13(4), 61-70.

Gong, H., et al. (2000). Lipid nutrition of juvenile Litopenaeus vannamei: I. Dietary cholesterol and de-oiled soy lecithin requirements and their interaction. Aquaculture, 190(3-4), 305-324.

González-Félix, M. L., Lawrence, A. L., Gatlin, D. M. III, \& Perez-Velazquez, M. (2002). Growth, survival and fatty acid composition of juvenile Litopenaeus vannamei fed different oils in the presence and absence of phospholipids. Aquaculture, 205, 325-343.

Hamre, K. (2016). Nutrient profiles of rotifers (Brachionus sp.) and rotifer diets from four different marine fish hatcheries. Aquaculture, 450, 136-142. https://dx.doi. org/10.1016/j.aquaculture.2015.07.016

Iannacone, J., \& Alvariño, L. (2007). Diversidad de invertebrados acuáticos de la bocatoma

de la atarjea en el Río Rímac, Lima Perú durante 1999. Biotempo, 7, 61-75.

Jain, A., \& Loeppert, R. H. (2000). Effect of competing anions on the adsorption of arsenate and arsenite by ferrihydrite. Journal of Environmental Quality, 29(5), 1422-1430.

Josileen, J., \& Menon, N. G. (2004). Larval stages of the blue swimmer crab, Portunus pelagicus (Linnaeus, 1758) (Decapoda, Brachyura). Crustaceana-International Journal of Crustacean Research, 77(7), 785-804.

Jusoh, M., Kasan, N. A., Hashim, F. S., Haris, N., Zakaria, M. F., Mohamed, N. N., ... \& Takahashi, K. (2020). Isolation of freshwater and marine indigenous microalgae species from Terengganu water bodies for potential uses as live feeds in aquaculture industry. International Aquatic Research, 12(1), 7483.DOI:10.22034/IAR(20).2020.671730.

Knuckey, R. M., Brown, M. R., Barrett, S. M., \& Hallegraeff, G. M. (2002). Isolation of new nanoplanktonic diatom strains and their evaluation as diets for juvenile Pacific oysters (Crassostrea gigas). Aquaculture, 211, 253-274.

Kreeger, D. A., \& Langdon, C. J. (1993). Effect of dietary protein content on growth of juvenile mussels, Mytilus trossulus (Gould 1850). Biol Bull, 185, 123-139.

Lee, K.-W., Dahms, H.-U., Park, H. G., \& Kang, J.-H. (2013). Population growth and productivity of the cyclopoid copepods Paracyclopina nana, Apocyclops royi and the harpacticoid copepod Tigriopus japonicus in mono and polyculture conditions: A laboratory study. Aquaculture Research, 44, 836-840.

Lim, L. C., Dhert, P., \& Sorgeloos, P. (2003). Recent developments in the application of live feeds in the freshwater ornamental fish culture. Aquaculture, 227(1-4), 319-331.

Loh Jiun Yan, Han Kiat, Alan Ong, Yii Siang Hii, Thomas J. Smith, Malcolm W. L o c k, \& Gideon Khoo. (2012). Highly unsaturated fatty acid (HUFA) retention in the freshwater cladoceran, Moina macrocopa, enriched with lipid emulsions. The Society of Israeli Aquaculture. Bamidgeh, IJA: 64. 2012. 637, 9 pages.

Maehre, H. K., Edvinsen, G. K., Eilertsen, K. E., \& Elvevoll, E. O. (2016). Heat treatment increases the protein bioaccessibility in the red seaweed dulse (Palmaria palmata), but not in the brown seaweed winged kelp (Alaria esculenta). J. Appl. Phycol., 28, 581-590.

Marsden, G., Richardson, N., Mather, P., \& Knibb, W. (2013). Reproductive behavioural difference between wildcaught and pond-reared Penaeus monodon prawn broodstock. Aquaculture, 402-403, 141-145.

Martin, L., Arenal, A., Fajardo, J., Pimental, E., Hidalgo, L., Pacheco, M., Garcia, C., \& Santiesteban, D. (2003). Complete and partial replacement of artemia naupli by Moina micrura during early post larval culture of white shrimp Litopenaeus schmitti. Aquaculture Nutrition, 12, 89-96. 
Müller-Navarra, D. C., Brett, M. T., Liston, A. M., \& Goldman, C. R. (2000). A highly unsaturated fatty acid predicts carbon transfer between primary producers and consumers. Nature, 403(6765), 74-77.

Munirasu, S., Uthayakumar, V., Arunkumar, P., \& Ramasubramanian, V. (2016). The effect of different feeds such as Chlorella vulgaris, Azolla pinnata and yeast on the population growth of Daphnia magna commonly found in freshwater systems.

Naman, N., Kassim, Z., \& Rasdi, N. W. (2021, February). The effect of copepod enrichedvegetable based diet on Giant Tiger Prawn (Penaeus monodon) post-larvae. In IOP Conference Series: Earth and Environmental Science, 674(1), 012081. IOP Publishing.

Nandini, S., Mayeli, S. M., \& Sarma, S. S. S. (2004). Effect of stress on the lifetable demography of Moina macrocopa. Hydrobiologia, 526, 245-254.

Nandini, S., Alonso-Soto, R., \& Sarma, S. S. S. (2013). Growth of Plankton (Scenedesmus acutus (Chlorophyceae) and Moina macracopa (Cladocera) on domestic wastewater. CLEAN-Soil, Air, Water, 41(1), 11-15.

Ng, W. K., Koh, C. B., Teoh, C. Y., \& Romano, N. (2015). Farm-raised tiger shrimp, Penaeus monodon, fed commercial feeds with added organic acids showed enhanced nutrient utilization, immune response and resistance to Vibrio harveyi challenge. Aquaculture, 449, 69-77.

Nguyen, N. H., Trinh, L. T., Chau, D. T., Baruah, K., Lundh, T., \& Kiessling, A. (2019). Spent brewer's yeast as a replacement for fishmeal in diets for giant freshwater prawn (Macrobrachium rosenbergii), reared in either clear water or a biofloc environment. Aquaculture Nutrition, 25(4), 970-979.

Olsen, A. I., A. MÆland, R., Waagbø, \& Y. Olsen . (2000). Effects of algal addition on stability of fatty acids and some water-soluble vitamins in juvenile Artemia franciscana. Aquaculture Nutrition, 6, 263- 273.
Oujifard, A., Seyfabadi, J., Kenari, A. A., \& Rezaei, M. (2012). Growth and apparent digestibility of nutrients, fatty acids and amino acids in Pacific white shrimp, Litopenaeus vannamei, fed diets with rice protein concentrate as total and partial replacement of fish meal. Aquaculture, 342, 56-61.

Pachaan Kola Chinatan, George John \& Athmanthan Balasundra. (2017). Performance evaluation of two priobiotic species on the growth, body composition and immune expression in P.monodon. Journal of Fisheries and Aquatic Science, 12, 157-167.

Panantharayil Shyne Anand, A. Panigrachi, \& Ravichandran. (2015). Growth, performance of Black Tiger Shrimp (Penaeus monodon) in substrate based zerowater exchange system India Journal of Geo Marine Science, 44(10), 1495-1503.

Rasdi, N. W., Suhaimi, H., Yuslan, A., Sung, Y. Y., Ikhwanuddin, M., Omar, S. S., Qin, J. G., Kassim, Z., \& Yusoff, F. M. (2018c). Effect of mono and binary diets on growth and reproduction of cyclopoid copepod. AACL Bioflux, 11(5), 1658-1671.

Rasdi, N. W., \& Qin, J. G. (2018a). Impact of food type on growth, survival and reproduction of the cyclopoid copepod Cyclopina kasignete as a potential live food in aquaculture. Aquaculture International, 26, 1281-1295.

Rasdi, Nadiah, W., \& Qin, Jian, G. (2018b). Copepod supplementation as a live food improved growth and survival of Asian Seabass Lates Calcarifer Larvae. Aquaculture Research, 49(11), 3606-613.

Rottmann, R. W., Scott Graves, J., Craig Watson, Roy, P. E. Yanong. (2014). Culture techniques of Moina: The ideal Daphnia for feeding freshwater fish fry. UF/IFAS Tropical Aquaculture Laboratory, 813, 6715230.

Samat, N. A., Yusoff, F. M., Rasdi, N. W., \& Karim, M. (2020). Enhancement of Live Food Nutritional Status with Essential 
Nutrients for Improving Aquatic Animal Health: A Review. Animals, 10(12), 2457.

Samocha, T. M. (2010). Use of intensive and super-intensive nursery systems. The shrimp book, theory and practice of Penaeid shrimp aquaculture (pp. 247-280). Nottingham, UK.

Sarma, S. s. s., Nandini, S., Morales-Ventura, J., Delgado-Martínez, I., \& GonzálezValverde, L. (2006). Effects of $\mathrm{NaCl}$ salinity on the population dynamics of freshwater zooplankton (rotifers and cladocerans). Aquatic Ecology, 40, 349-360.

Sarlin, P. J., \& Philip, R. (2016). Marine yeasts as feed supplement for Indian white prawn Fenneropenaeus indicus: Screening and Testing the Efficacy. International Journal of Current Microbiology and Applied Sciences, 5(1), 55-70.

Scott, A. P., \& Middleton, C. (1979). Unicellular algae as a food for turbot (Scophthalmus maximus L.) larvae - The importance of dietary long-chain polyunsaturated fatty acids. Aquaculture, 18, 227-242.

Shailender, M., Krishna, P. V., Suresh Babu, Ch., \& Srikanth, B. (2012). Impact of disease on the growth and survival of giant freshwater prawn, Macrobrachium rosenbergii (De Man) larvae in the hatchery level. World $J$ Fish Mar Sci, 4, 620-625.

Sharawy, Z. Z., Ashour, M., Abbas, E., Ashry, O., Helal, M., Nazmi, H., ... \& El-Haroun, E. (2020). Effects of dietary marine microalgae, Tetraselmis suecica, on production, gene expression, protein markers and bacterial count of Pacific white shrimp Litopenaeus vannamei. Aquaculture Research.

Shepard, A. K. (2015). Responses of heterotrophic and autotrophic pico-and nano-plankton to nutrient availability and enrichment across marine systems in the Northern Gulf of Mexico (Doctoral dissertation).
Singh, K., Munilkumar, S., Sahu, N. P., Das, A., \& Devi, G. A. (2019). Feeding HUFA and vitamin C-enriched Moina micrura enhances growth and survival of Anabas testudineus (Bloch, 1792) larvae. Aquaculture, 500, 378-384.

Uawisetwathana, U., Leelatanawit, R., Klanchui, A., Prommoon, J., Klinbunga, S., \& Karoonuthaisiri, N. (2011). Insights into eyestalk ablation mechanism to induce ovarian maturation in the black tiger shrimp. PloS one, 6(9), e24427.

Uddin, M., Nazim, M., Shahadat Hossain, Nani Gopal Das, M. Shah Nawaz Chowdhury, \& Prabal Barua. (2010). Determination of optimum stocking density of Macrobrachium rosenbergii larvae using multiple feed in a commercial hatchery at Cox's Bazar, Bangladesh.

Wong, T. T., \& Y. Zohar. (2015). Production of reproductively sterile fish: A mini review of germ cell elimination technologies. Gen Comp Endocrinol, 221, 3-8.

Yanar, Y., \& Celik, M. (2006). Seasonal amino acid profiles and mineral content of green tiger shrimp (Penaus semisulcatus, De Haan, 1844) and speckled shrimp (Metapenaus monoceros, Fabricus 1789) from the Eastern Mediterranean Sea. Food Chemistry, 94, 33-36.

Yuslan, A., Najuwa, S., Hagiwara, A., Ghaffar, M. A., Suhaimi, H., \& Rasdi, N. W. (2021). Production performance of Moina macrocopa (Straus 1820) (crustacea, cladocera) cultured in different salinities: the effect on growth, survival, reproduction, and fatty acid composition of the neonates. Diversity, 13(3), 105.

Zaleha, K., \& I. Busra. (2012). Culture of harpacticoid copepods: Understanding the reproduction and effect of environmental factors. Muchlisin, Z. (Ed.), Aquaculture, (p.343-360). 